Research Article

\title{
Phenolic Content, Antioxidant Activity, Anti-Inflammatory Potential, and Acute Toxicity Study of Thymus leptobotrys Murb. Extracts
}

\author{
Asmaa Oubihi, ${ }^{1}$ Hanae Hosni, ${ }^{2}$ Issmail Nounah, ${ }^{3}$ Abdessamad Ettouil, ${ }^{1}$ \\ Hicham Harhar $\left(\mathbb{1},{ }^{4}\right.$ Katim Alaoui, ${ }^{2}$ Mohammed Ouhssine, ${ }^{1}$ and Zineb Guessous ${ }^{1}$ \\ ${ }^{1}$ Laboratory of Agro-Physiology, Biotechnology, Environment and Quality, Faculty of Science, \\ Ibn Tofail University, Kenitra, Morocco \\ ${ }^{2}$ Pharmacodynamy Research Team ERP, Laboratory of Pharmacology and Toxicology, Faculty of Medicine and Pharmacy, \\ Mohammed V University, Rabat, Morocco \\ ${ }^{3}$ Laboratory of Chemistry and Organic and Bioorganic Synthesis, Faculty of Science, Geophysics, \\ Natural Patrimony and Green Chemistry (GEOPAC) Research Center, University Mohammed V, Rabat, Morocco \\ ${ }^{4}$ Laboratory of Nanotechnology, Materials and Environment, Department of Chemistry, Faculty of Science, \\ Mohammed V University in Rabat, BP. 1014, Rabat, Morocco \\ Correspondence should be addressed to Hicham Harhar; hichamoo79@yahoo.fr
}

Received 13 July 2020; Revised 5 September 2020; Accepted 10 September 2020; Published 18 September 2020

Academic Editor: Tzi Bun Ng

Copyright ( 2020 Asmaa Oubihi et al. This is an open access article distributed under the Creative Commons Attribution License, which permits unrestricted use, distribution, and reproduction in any medium, provided the original work is properly cited.

\begin{abstract}
Thymus leptobotrys is a medicinal plant belonging to the Lamiaceae family, endemic in Morocco, and used in traditional medicine. The present work aims to study the phenolic compounds, the antioxidant activity, the anti-inflammatory effect, and the toxicity of two ethanolic and methanolic extracts of Thymus leptobotrys aerial part. The yield of the methanolic extraction (22.2\%) is higher than that of the ethanolic extraction (15.8\%) and is characterized by higher contents of polyphenols $243.08 \mathrm{mg} / \mathrm{g} \mathrm{GAE} \mathrm{(mg/g} \mathrm{of}$ gallic acid), flavonoids $179.28 \mathrm{mg} / \mathrm{g} \mathrm{RE}$ (mg/g of rutin), and tannins $39.31 \mathrm{mg} / \mathrm{g} \mathrm{CE} \mathrm{(mg/g} \mathrm{of} \mathrm{catechin).} \mathrm{The} \mathrm{in} \mathrm{vitro} \mathrm{measurement}$ of antioxidant activity with the 2,2-diphenyl-1-picrylhydrazyl (DPPH) radical reduction test and Trolox equivalent antioxidant capacity (TEAC) test demonstrates the higher performance of the methanolic extract. The evaluation of the anti-inflammatory effect in vivo on adult Wistar female rats leads to a very significant decrease in the inflammation of the edema compared to the standard drug (indomethacin) and the control group. The toxicity test reveals that both extracts showed no toxicity within an LD50 above $2000 \mathrm{mg} / \mathrm{kg}$ body weight of the rats.
\end{abstract}

\section{Introduction}

Oxidative stress causes significant damage that accelerates cellular aging. This aging process leads to serious pathologies such as cancer, cardiovascular disease, diabetes, neurodegenerative disease, inflammation, digestive diseases, and metabolic syndrome [1-3]. Several situations in daily life lead to the production of free radicals responsible for oxidative stress. These include endogenous overproduction of inflammatory oxidative agents, free radical overproduction (tobacco, alcohol, drugs, pollution, and pesticides), and a decrease in the antioxidant capacity of foodborne vitamins and trace elements $[2,4,5]$. The use of currently available synthetic antioxidant molecules is being questioned because of potential health risks $[2,6]$. The search for natural antioxidants, mainly carotenoids, polyphenols (flavonoids and phenols acids), and vitamins (mainly vitamins $\mathrm{C}$ and E) [7] derived from plant materials, is growing rapidly and is based on the characterization of endemic plants. Typically, these natural antioxidants, particularly polyphenols, show evidence of a broad variety of biological effects, such as antiplasmodial, antimicrobial, antiarthritic, anticancer, and anti-inflammatory effects $[8,9]$. 
The medicinal plant sector in Morocco has a rich and varied flora with very marked endemism [10]. The species of Thymus L. (Lamiaceae) are perennial, aromatic herbs, and widely used in the Mediterranean Basin [11]. Thymus leptobotrys Murb. is an endemic species of southern Morocco traditionally used in the treatment of bronchitis, indigestion, whooping cough, and rheumatism [12] and has antifungal, antimicrobial, analgesic, insecticidal, antioxidant, and antiviral properties [13-16].

No studies regarding the in vivo anti-inflammatory effect of Thymus leptobotrys were conducted previously to our knowledge. The present work is part of the valorization of Moroccan aromatic and medicinal plants. Its objective is to study the phenolic compounds, the antioxidant activity, the in vivo anti-inflammatory effect, and the acute toxicity of ethanolic and methanolic extracts of Thymus leptobotrys.

\section{Materials and Methods}

2.1. Plant Material. The aerial parts of Thymus leptobotrys are recovered in the region of Sidi Mzal, a small Berber village in the mountains of the Moroccan Anti-Atlas (N $29^{\circ} 86^{\prime} / \mathrm{W} 08^{\circ} 88^{\prime}$ ) during the harvest period (April-June 2017). The identification is made at the Laboratory of Botany and Plant Protection, Ibn Tofail University, Kenitra, Morocco. The sample is dried at room temperature and then ground and stored in sterile bags until analysis.

2.2. Animals. Adult female Wistar rats (180 to $230 \mathrm{~g}$ ) are used for testing anti-inflammatory activity and acute toxicity. The animals are reared in the Animal Center of the Faculty of Medicine and Pharmacy of Mohammed V University in Rabat, under standard experimental conditions, where the temperature varies between 20 and $25^{\circ} \mathrm{C}$ with a 12-hour photoperiodic cycle. The study was conducted in accordance with the accepted principles set out in the report "Guide for the care and use of laboratory animals" prepared by the National Academy of Sciences and published by the National Institutes of Health [17].

2.3. Extraction of Plant Samples. $50 \mathrm{~g}$ of the powder of the aerial part of Thymus leptobotrys is placed in a cartridge and placed in the Soxhlet extractor [18]. The flask is filled with $300 \mathrm{ml}$ methanol for the methanolic extract and $300 \mathrm{ml}$ ethanol for the ethanolic extract, and the flask is placed on a heater. When heated, the solvent evaporates, condenses in the cooler, falls back into the Soxhlet extractor, solubilizes the active ingredients, and returns to the recovery flask: the operation is repeated several times for 6 hours until the powder is completely depleted. The extract solution is cooled to room temperature, filtered through a filter paper, and then freed of all traces of solvent by means of a rotary vacuum evaporator at $40^{\circ} \mathrm{C}$. The extracts are stored in hermetically sealed brown glass vials at $4^{\circ} \mathrm{C}$. The extract yield (\%) is calculated as follows:

$$
\text { yield } \%=\frac{\operatorname{extract}(\mathrm{g})}{\operatorname{dry} \operatorname{matter}(\mathrm{g})} \times 100 \text {. }
$$

\subsection{Determination of Phenolic Content}

2.4.1. Total Phenol Content. The total content of polyphenol is determined by the Folin-Ciocalteu reagent protocol as described by Nounah et al. [19]. First, $0.5 \mathrm{~mL}$ of the extract is mixed with $2.5 \mathrm{~mL}$ of Folin-Ciocalteu reagent diluted 1/10 with distilled water. Then, $4 \mathrm{~mL}$ of $7.5 \% \mathrm{Na}_{2} \mathrm{CO}_{3}(\mathrm{w} / \mathrm{v})$ is added, followed immediately by incubation for $30 \mathrm{~min}$ at $45^{\circ} \mathrm{C}$. The spectrophotometric reading at $760 \mathrm{~nm}$ is taken against a blank. The calibration curve is performed with gallic acid at concentrations between 2.5 and $250 \mu \mathrm{g} / \mathrm{mL}$. The total content of phenols is expressed in $\mathrm{mg}$ of gallic acid equivalent (GAE) per gram of extract (mg GAE/g E).

2.4.2. Total Flavonoid Content. The total content of flavonoids is determined using the aluminum chloride colorimetric method [19]. $0.25 \mathrm{~mL}$ of the extract is placed in a test tube containing $1.25 \mathrm{~mL}$ of distilled water, followed by the addition of $0.075 \mathrm{~mL}$ of sodium nitrite solution $\mathrm{NaNO}_{3}(5 \%)$, and the mixture is kept at rest for 5 minutes. Then $0.15 \mathrm{~mL}$ of $10 \%$ aluminum chloride is added. After $6 \mathrm{~min}, 0.5 \mathrm{~mL} 1 \mathrm{M}$ sodium hydroxide is added. The mixture is diluted with $0.275 \mathrm{~mL}$ of distilled water. The final mixture is then incubated for 30 minutes in the dark at room temperature, and the absorbance is measured at $510 \mathrm{~nm}$. The flavonoid content is expressed in $\mathrm{mg}$ of rutin equivalent (RE) per gram of extract (mg RE/g E).

2.4.3. Total Tannin Content. The total content of condensed tannins is determined by the acidic vanillin method [20]. $500 \mu \mathrm{L}$ of extract solution is mixed with $3 \mathrm{~mL}$ of $4 \%$ vanillin-methanol solution and $1.5 \mathrm{~mL}$ hydrochloric acid. The mixture is allowed to stand in the dark for $15 \mathrm{~min}$. The absorbance is measured at $500 \mathrm{~nm}$. The calibration curve for catechin is constructed from the concentrations from 30 to $1000 \mu \mathrm{g} / \mathrm{mL}$. The content of condensed tannins is expressed in $\mathrm{mg}$ of catechin equivalent (CE) per gram of extract (mg CE/g E).

\subsection{Antioxidant Activity}

2.5.1. DPPH Free Radical Scavenging. The free radical scavenging activity of the extracts was measured by DPPH using the method described by Re et al. [21]. A $0.2 \mathrm{mM}$ solution of DPPH is prepared in methanol or ethanol, and $0.5 \mathrm{~mL}$ of this solution is added to $2.5 \mathrm{~mL}$ of the sample. After vigorous shaking, the mixture is kept in the dark for $30 \mathrm{~min}$. The absorbance is measured at $517 \mathrm{~nm}$. Trolox is used as a reference compound. The experiment is performed in triplicate. The ability to recover the $\mathrm{DPPH}$ radical is measured using the following equation:

$$
\text { \%inhibition }=\frac{A_{0}-A_{1}}{A_{0}} \times 100,
$$

where $A_{0}$ is the absorbance of the negative control and $A_{1}$ is the absorbance of the sample.

The scavenging activity is expressed by the IC50 which represents the sample concentration required to inhibit $50 \%$ of the free radical scavenging activity. 
2.5.2. Trolox Equivalent Antioxidant Capacity (TEAC). The ABTS radical scavenging activity is determined by the protocol described by Nounah et al. [22]. Stock solutions of $7 \mathrm{mM}$ ABTS and $2.4 \mathrm{mM}$ potassium persulfate $\left(\mathrm{K}_{2} \mathrm{~S}_{2} \mathrm{O}_{8}\right)$ in identical volumes are kept in the dark for sixteen hours at room temperature. Prior to testing, the ABTS+ solution is diluted in methanol or ethanol to give an absorbance of $0.700 \pm 0.02$ at $734 \mathrm{~nm}$. $2 \mathrm{~mL}$ of the resulting solutions is allowed to react with $200 \mu \mathrm{L}$ of the sample $(2 \mathrm{mg} / \mathrm{mL})$, and the absorbance is measured after $30 \mathrm{~min}$ at $734 \mathrm{~nm}$. The same procedure is used with Trolox at different concentrations (from 5 to $100 \mu \mathrm{g} / \mathrm{mL}$ ). The percentage of $\mathrm{ABTS}^{+}$inhibition by different concentrations is calculated, and the antioxidant power of the sample is represented in Trolox equivalent (mg TE/g sample). The test is performed in triplicate.

2.6. Acute Toxicity Study. The acute toxicity study of T. leptobotrys extracts is evaluated on adult rats in accordance with the Organization for Economic Cooperation and Development 423 guidelines [23, 24]. After a fasting period of $3-4 \mathrm{~h}$, the body weight of each animal is measured to determine the dose to be administered orally, expressed as mg extract per $\mathrm{kg}$ body weight. The animals are arbitrarily divided into three groups of six rats $(n=6)$. The first and second groups receive methanolic and ethanolic extracts from T. leptobotrys at doses of 300 and $2000 \mathrm{mg} / \mathrm{kg}$, and the third group (control group) is given distilled water (control vehicle) orally. Signs of toxicity evaluated are general behavioral symptoms, changes in body weight, ingestion of water and food, respiration, convulsions, and mortality. They are assessed systematically for each group during the first few hours and then 14 days after treatment. The 50\% lethal dose (LD50) is determined according to the protocol described in guidelines 423 [23].

2.7. Anti-Inflammatory Effect. The anti-inflammatory effect is studied using the carrageenan-induced paw edema method [25, 26]. Wistar rats are divided into four groups $(n=6)$. The animals were fasted for 18 hours prior to testing. The groups of rats were given different oral concentrations of T. leptobotrys extracts (300 and $600 \mathrm{mg} / \mathrm{kg}$ ). The control group receives distilled water while the last group receives indomethacin $(10 \mathrm{mg} / \mathrm{kg})$ as the reference drug. After 30 minutes, all rats are injected subcutaneously with carrageenan solution $(0.05 \mathrm{~mL}$ of $1 \%$ carrageenan suspended in $0.9 \% \mathrm{NaCl}$ ) into the subplantar region of the left hind paw. The paw volumes of the rats were recorded with a LE7500 plethysmometer just before the carrageenan injection $\left(V_{0}\right)$, then at $1 \mathrm{~h} 30 \mathrm{~min}, 3 \mathrm{~h}$, and $6 \mathrm{~h}$ after the carrageenan injection $\left(V_{t}\right)$. Anti-inflammatory effect is calculated using the following equation [27]:

\%inhibition $=\frac{\left(V_{t}-V_{0}\right) \text { control }-\left(V_{t}-V_{0}\right) \text { treated group }}{\left(V_{t}-V_{0}\right) \text { control }} \times 100$.
2.8. Statistical Analysis. The data are expressed as mean values \pm standard deviation for each measurement and analyzed by means of analysis of variance (one-way ANOVA) followed by Tukey posttests. The statistical study is performed using GraphPad Prism 8 software. A probability of $P<0.05$ indicates that the values are considered statistically significant.

\section{Results and Discussion}

3.1. Extraction Yield. The yield of the methanolic extract is around $22.2 \%$, higher than that of ethanolic extract (15.8\%).

3.2. Determination of Phenolic Content. Table 1 shows the total content of phenolics (TCP), flavonoids (TCF), and condensed tannins (CCT) of methanolic and ethanol extracts of T. leptobotrys. The highest TCP, TCF, and CCT are found in the methanolic extract. The ethanolic extract, on the other hand, has slightly lower levels of TCP and TCF, while the content of CCT is extremely low. This variation in results clearly shows that the difference in polarity of the solvents influences the extraction of phenolic compounds [28].

3.3. Antioxidant Activity. The antioxidant capacity of methanolic and ethanol extracts of T. leptobotrys was studied using two different methods: DPPH and ABTS radical absorption capacity (Table 2). A low IC50 value indicates significant antioxidant activity. According to the DPPH method, both types of extracts have significant antioxidant activity (Table 2), especially the methanolic extract (IC50 $=12.363 \pm 0.324 \mu \mathrm{g} / \mathrm{mL})$, compared to the ethanolic extract $(\mathrm{IC} 50=20.693 \pm 0.182 \mu \mathrm{g} / \mathrm{mL})$. In both cases, the IC50s are higher than that of the Trolox standard (IC50 $=1.810 \pm 0.017 \mu \mathrm{g} / \mathrm{mL})$. The antioxidant activity of T. leptobotrys extracts, according to the ABTS test, shows that the methanolic extract has a powerful antioxidant activity of the order of $930.935 \pm 1.513 \mathrm{mg}$ TE/g extract, higher than that found in the ethanolic extract $(860.309 \pm 0.954 \mathrm{mg}$ $\mathrm{TE} / \mathrm{g})$.

The methanolic extract of the aerial part of T. leptobotrys has a higher DPPH antioxidant activity than both the methanolic extract of the leaves of $T$. leptobotrys $(\mathrm{IC} 50=1950 \mu \mathrm{g} / \mathrm{mL})$ and the methanolic extract of the stems of T. leptobotrys $(\mathrm{IC} 50=430 \mu \mathrm{g} / \mathrm{mL})$ using the DPPH test [29]. Thus, the whole aerial part of the plant is logically more active than individual leaves or stems.

Comparison of the results with the other studies is however not appropriate for the following two reasons: on the one hand, the antioxidant content is strongly influenced by the type of solvent used, and on the other hand, the results are expressed in caffeine equivalents or Trolox equivalents, which makes the results not directly comparable [30].

The important antioxidant activity of the methanolic extract of Thymus leptobotrys to the DPPH and ABTS radical could be explained by its richness in phenolic compounds. There is indeed a correlation between the antioxidant activity and content of phenolic compounds [31-33]. On the 
TABLE 1: Total content of phenols (TCP), flavonoids (TCF), and condensed tannins (CCT) of ethanolic and methanolic extracts of Thymus leptobotrys.

\begin{tabular}{lccc}
\hline Extracts & TCP $(\mathrm{mg} \mathrm{GAE} / \mathrm{g} \mathrm{E})$ & TCF $(\mathrm{mg} \mathrm{RE} / \mathrm{g} \mathrm{E})$ & CCT $(\mathrm{mg} \mathrm{CE} / \mathrm{g} \mathrm{E})$ \\
\hline Methanol extract & $243.08 \pm 2.911$ & $179.28 \pm 0.922$ & $39.31 \pm 0.441$ \\
Ethanol extract & $214.26 \pm 2.079$ & $144.41 \pm 1.537$ & $3.06 \pm 0.200$ \\
\hline
\end{tabular}

TABLE 2: Antioxidant activity of ethanolic and methanolic extracts of Thymus leptobotrys.

\begin{tabular}{lcr}
\hline Extracts & DPPH $(\mathrm{IC} 50 \mu \mathrm{g} / \mathrm{mL})$ & ABTS (mg TE/g extract) \\
\hline Methanol extract & $12.363 \pm 0.324$ & $930.935 \pm 1.513$ \\
Ethanol extract & $20.693 \pm 0.182$ & $860.309 \pm 0.954$ \\
Trolox & $1.850 \pm 0.017$ & - \\
\hline
\end{tabular}

TABle 3: Study of the acute toxicity of ethanolic and methanolic extracts of Thymus leptobotrys administered by gavage to rats.

\begin{tabular}{|c|c|c|c|c|c|c|}
\hline \multirow{2}{*}{ Treatments } & \multirow{2}{*}{ Dose $\mathrm{mg} / \mathrm{kg}$} & \multirow{2}{*}{ Mortality } & \multirow{2}{*}{ Toxic symptoms } & \multicolumn{3}{|c|}{ Changes in body weight $(\mathrm{g})$} \\
\hline & & & & $1^{\text {st }}$ day & $14^{\text {th }}$ day & Difference \\
\hline Methanol extract & 2000 & - & None & $185.03 \pm 1.02$ & $197.83 \pm 2.62$ & +12.8 \\
\hline Ethanol extract & 2000 & - & None & $185.63 \pm 2.42$ & $197.86 \pm 1.37$ & +12.23 \\
\hline Control & - & - & - & $186.03 \pm 1.77$ & $199.06 \pm 0.68$ & +13.03 \\
\hline
\end{tabular}

TABle 4: Percentage inhibition of left hind leg volume in rats treated with Thymus leptobotrys ethanolic and methanolic extracts.

\begin{tabular}{|c|c|c|c|}
\hline \multirow[t]{2}{*}{ Treatments (mg/kg) } & \multicolumn{3}{|c|}{$\begin{array}{l}\text { Inhibition of edema induced by } \\
\text { carrageenan }(\%)\end{array}$} \\
\hline & $1 \mathrm{~h} 30 \mathrm{~min}$ & $3 \mathrm{~h}$ & $6 \mathrm{~h}$ \\
\hline Indomethacin, 10 & 76.77 & 75.78 & 61.37 \\
\hline Methanol extract, 300 & 65.87 & 64.12 & 57.51 \\
\hline Methanol extract, 600 & 90.04 & 84.30 & 75.10 \\
\hline Ethanol extract, 300 & 68.24 & 61.43 & 55.36 \\
\hline Ethanol extract, 600 & 83.88 & 76.68 & 62.66 \\
\hline
\end{tabular}

other hand, many studies have reported that phenolic compounds are often known by their antioxidant activity [34-36].

3.4. Acute Toxicity Study. The acute toxicity study of methanol and ethanol extracts of T. leptobotrys showed no mortality or clinical signs of toxicity in each group of animals all through the fourteen days of study. At $2000 \mathrm{mg} / \mathrm{kg}$, rats showed no signs of changes in behavioral patterns or undesirable pathology or weight loss (Table 3). Ethanol and methanol extracts of $T$. leptobotrys can be classified as category 5 and are considered to be nontoxic by the oral route [23].

3.5. Anti-Inflammatory Effect. The anti-inflammatory effect of ethanolic and methanolic extracts is evaluated by the carrageenan-induced rat paw edema method. The results are presented in Table 4 and Figures 1 and 2. Six hours after administration of $T$. leptobotrys at $600 \mathrm{mg} / \mathrm{kg}$ extract, the volume of edema decreased notably compared to the control group $(P<0.001)$ (Figures 1 and 2$)$. Rats treated with methanol and ethanol extracts showed the greatest decrease in inflammation (90.04\% and $83.88 \%$, respectively) after $1.5 \mathrm{~h}$ of carrageenan injection. This reduction in edema was

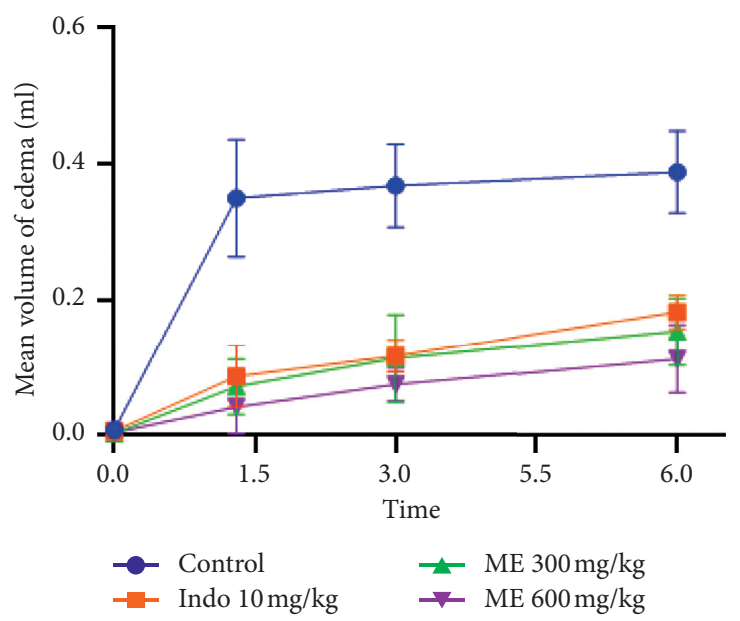

FIgUre 1: Influence of ME: methanolic extract of Thymus leptobotrys (300 and $600 \mathrm{mg} / \mathrm{kg}$ ) on carrageenan edema. The data represent the difference in the mean volume of the edema (mean $\pm \mathrm{SEM}$ ), $n=6 . P \leq 0.001$ versus witness.

greater than that of indomethacin $76.77 \%$ (Table 4) and was maintained throughout the observation period. Based on these results, it can be concluded that T. leptobotrys extracts act within the first hour on the initial phase of inflammation, just like indomethacin.

Carrageenan-induced paw edema is due to cyclooxygenase and lipoxygenase. The cyclooxygenase enzyme is directly involved in inflammation through prostaglandin production while lipoxygenase indirectly causes an inflammatory response $[7,37]$. Thus, the anti-inflammatory power of methanolic and ethanol extracts of T. leptobotrys can be explained by an inhibitory action exerted on cyclooxygenases. The inhibition of cyclooxygenases may be due to the richness of methanolic and ethanolic extracts in polyphenolic constituents. Polyphenols prevent the 


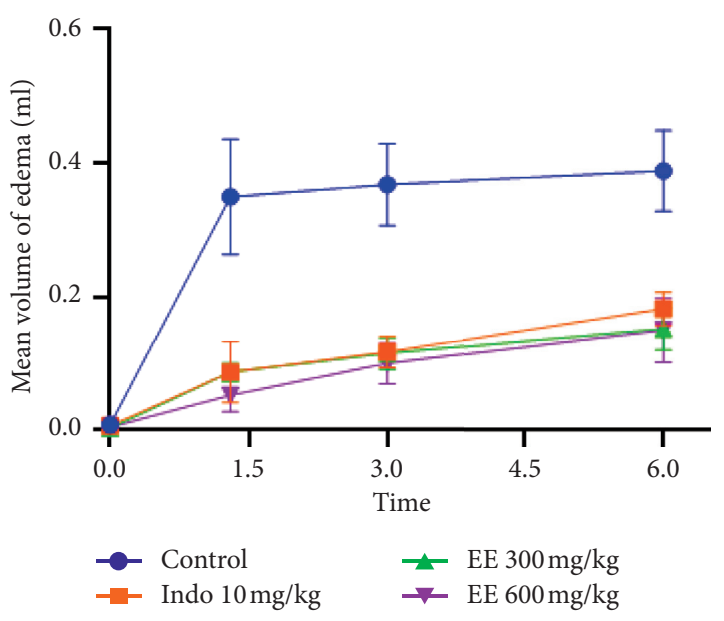

FIGURE 2: Influence of EE: ethanolic extract of Thymus leptobotrys (300 and $600 \mathrm{mg} / \mathrm{kg}$ ) on carrageenan edema. The data represent the difference in the mean volume of the edema (mean \pm SEM), $n=6$. $P \leq 0.001$ versus witness.

formation of prostaglandins that cause inflammation [38]. Tannins and flavonoids also contribute to the anti-inflammatory effect through their ability to inhibit the production of 5 proinflammatory mediators such as lipoxygenase, prostaglandins, cyclooxygenase, serotonin, histamines, and cytokines such as IL-8, TNF- $\alpha$, or IL-1 $\beta$ [39-41].

\section{Conclusion}

The methanolic and ethanolic extracts' chemical analysis of the aerial part of Thymus leptobotrys reveals their phenolic compounds abundance. Overall, the methanolic extract has the highest levels of phenolic compounds as well as a more pronounced antioxidant activity using both $\mathrm{DPPH}$ and ABTS methods, with values of IC50 $=12.363 \pm 0.324 \mu \mathrm{g} / \mathrm{mL}$ and $930.935 \pm 1.513 \mu \mathrm{g}$ extract $\mathrm{TE} / \mathrm{g}$, respectively. The decrease in leg edema in adult rats after 6 hours of administrating $600 \mathrm{mg}$ extract/ $/ \mathrm{kg}$ shows a strong anti-inflammatory effect for both extracts. The toxicity test indicates an LD50 above $2000 \mathrm{mg} / \mathrm{kg}$ for both extracts. These results show the presence of bioactive molecules in the aerial fraction of Thymus leptobotrys. Further studies for future use against diseases due to oxidative stress are recommended.

\section{Data Availability}

All data supporting the findings are adequately included within the article.

\section{Conflicts of Interest}

The authors declare that they have no conflicts of interest.

\section{Acknowledgments}

The author Asmaa Oubihi is extremely thankful to all coauthors for their valuable contribution. Moreover, many thanks go to Pr. Zidane Lahcen (Laboratory of Botany and Plant Protection, Ibn Tofail University, Kenitra, Morocco) for plant authentication. Special thanks are due to all members of the Laboratory of Pharmacology and Toxicology, Faculty of Medicine and Pharmacy, Mohammed V University, Rabat, Morocco, especially to Fatima Zahrae Bellaoui for her advice and help.

\section{References}

[1] E. Köksal, E. Bursal, İ. Gülçin et al., “Antioxidant activity and polyphenol content of Turkish thyme (Thymus vulgaris) monitored by liquid chromatography and tandem mass spectrometry," International Journal of Food Properties, vol. 20, no. 3, pp. 514-525, 2017.

[2] D. Awa, Y. Konan, S. Youssouf, T. B. F. Honora, B. Adama, and K. M. Witabouna, "Pouvoir antioxydant et teneurs en composés phénoliques de deux espèces du genre Albertisia: Albertisia cordifolia (Mangenot \& J. Miège) Forman et Albertisia scandens (Mangenot \& J. Miège) Forman (Menispermaceae)," European Scientific Journal, vol. 14, no. 30, p. 128, 2018.

[3] E. Todirascu-Ciornea, H. A. S. El-Nashar, N. M. Mostafa et al., "Schinus terebinthifolius essential oil attenuates scopolamineinduced memory deficits via cholinergic modulation and antioxidant properties in a zebrafish model," Evidence-Based Complementary and Alternative Medicine, vol. 2019, Article ID 5256781, 11 pages, 2019.

[4] R. S. Sohal, R. J. Mockett, and W. C. Orr, "Mechanisms of aging: an appraisal of the oxidative stress hypothesis," Free Radical Biology and Medicine, vol. 33, no. 5, pp. 575-586, 2002.

[5] A. Favier, "Le stress oxydant," L’Actualité Chimique, vol. 108, 2003.

[6] Z. Liu and L. Yang, "Antisolvent precipitation for the preparation of high polymeric procyanidin nanoparticles under ultrasonication and evaluation of their antioxidant activity in vitro," Ultrasonics Sonochemistry, vol. 43, pp. 208-218, 2018.

[7] M. E. Islam, K. M. D. Islam, M. M. Billah, R. Biswas, M. H. Sohrab, and S. M. M. Rahman, "Antioxidant and antiinflammatory activity of Heritiera fomes (Buch.-Ham), a mangrove plant of the Sundarbans," Advances in Traditional Medicine, vol. 20, no. 2, pp. 189-197, 2019.

[8] K. Esseh, Y.-G. Afanyibo, K. Y. S. Ahama-Esseh et al., "Screening phytochimique, étude toxicologique, évaluation des activités antiplasmodiale et antiradicalaire de la tige feuillée de Senna occidentalis Linn (Fabaceae)," European Scientific Journal, vol. 15, no. 6, 2019.

[9] A. Saleem, M. Saleem, and M. F. Akhtar, "Antioxidant, antiinflammatory and antiarthritic potential of Moringa oleifera Lam: an ethnomedicinal plant of Moringaceae family," South African Journal of Botany, vol. 128, pp. 246-256, 2020.

[10] C. Sauvage and C. Raynaud, "Catalogue des végétaux vasculaires de Talassemtane (rif occidental)," in Etude de Certains Milieux du Maroc et de Leur Évolution Récente, pp. 143-178, Centre National de la Recherche Scientifique, Paris, France, 1974.

[11] H. Ismaili, L. Milella, S. Fkih-Tetouani et al., "In vivo topical anti-inflammatory and in vitro antioxidant activities of two extracts of thymus satureioides leaves," Journal of Ethnopharmacology, vol. 91, no. 1, pp. 31-36, 2004.

[12] J. Bellakhdar, "Medicinal plants in North Africa and basic care," Handbook of Modern Herbal Medicine, Fennec Press, Casablanca, Morocco, 2006.

[13] F. Amarti, B. Satrani, M. Ghanmi et al., "Composition chimique et activité antimicrobienne des huiles essentielles de 
Thymus algeriensis Boiss. \& Reut. et Thymus ciliatus (Desf.) Benth. du Maroc," Biotechnologie, Agronomie, Société et Environnement, vol. 14, pp. 141-148, 2010.

[14] K. Elhabazi, A. Ouacherif, A. Laroubi et al., "Analgesic activity of three thyme species, Thymus satureioides, Thymus maroccanus and Thymus leptobotrys," African Journal of Microbiology Research, vol. 2, pp. 262-267, 2008.

[15] F. Amarti, M. El Ajjouri, M. Ghanmi et al., "Composition chimique, activité antimicrobiennne et antioxydante de l'huile essentielle de Thymus zygis du Maroc," Phytothérapie, vol. 9, no. 3, pp. 149-157, 2011.

[16] C. A. Jamali, A. Kasrati, K. Bekkouche et al., "Phenological changes to the chemical composition and biological activity of the essential oil from Moroccan endemic thyme (Thymus maroccanus Ball)," Industrial Crops and Products, vol. 49, pp. 366-372, 2013.

[17] K. Sayah, L. Chemlal, I. Marmouzi, M. El Jemli, Y. Cherrah, and M. E. A. Faouzi, "In vivo anti-inflammatory and analgesic activities of Cistus salviifolius (L.) and Cistus monspeliensis (L.) aqueous extracts," South African Journal of Botany, vol. 113, pp. 160-163, 2017.

[18] O. R. Alara, N. H. Abdurahman, and C. I. Ukaegbu, "Soxhlet extraction of phenolic compounds from Vernonia cinerea leaves and its antioxidant activity," Journal of Applied Research on Medicinal and Aromatic Plants, vol. 11, pp. 12-17, 2018.

[19] I. Nounah, A. Hajib, A. Oubihi et al., "Phytochemical screening and biological activity of leaves and stems extract of hammada scoparia," Moroccan Journal of Chemistry, vol. 7, pp. 7-1, 2019.

[20] S. Haida, A. Kribii, and A. Kribii, "Chemical composition, phenolic content and antioxidant capacity of Haloxylon scoparium extracts," South African Journal of Botany, vol. 131, pp. 151-160, 2020.

[21] R. Re, N. Pellegrini, A. Proteggente, A. Pannala, M. Yang, and C. Rice-Evans, "Antioxidant activity applying an improved ABTS radical cation decolorization assay," Free Radical Biology and Medicine, vol. 26, no. 9-10, pp. 1231-1237, 1999.

[22] I. Nounah, A. Hajib, H. Harhar et al., "Chemical composition and antioxidant activity of Lawsonia inermis seed extracts from Morocco," Natural Product Communications, vol. 12, no. 4, 2017.

[23] Organisation for Economic Co-operation and Development (OECD), Guidelines for Testing of Chemical, Guideline 423. Acute Oral Toxicity e Acute Toxic Class Method, Organisation for Economic Co-operation and Development, Paris, France, 2002.

[24] M. El Jemli, R. Kamal, I. Marmouzi et al., "Chemical composition, acute toxicity, antioxidant and anti-inflammatory activities of Moroccan Tetraclinis articulata L." Journal of Traditional and Complementary Medicine, vol. 7, no. 3, pp. 281-287, 2017.

[25] C. A. Winter, E. A. Risley, and G. W. Nuss, "Carrageenininduced edema in hind paw of the rat as an assay for antiinflammatory drugs," Experimental Biology and Medicine, vol. 111, no. 3, pp. 544-547, 1962.

[26] A. Bounihi, G. Hajjaj, R. Alnamer, Y. Cherrah, and A. Zellou, "In vivo potential anti-inflammatory activity of Melissa officinalis L. essential oil," Advances in Pharmacological Sciences, vol. 2013, Article ID 1, 7 pages, 2013.

[27] M. T. Saénz, M. D. García, and M. A. Fernández, "Antiinflammatory activity and acute toxicity of Anredera leptostachys," Phytomedicine, vol. 5, no. 3, pp. 195-198, 1998.
[28] A. O. Bolanle, A. S. Funmilola, and A. Adedayo, "Proximate analysis, mineral contents, amino acid composition, antinutrients and phytochemical screening of brachystegia eurycoma harms and pipper guineense schum and thonn," American Journal of Food and Nutrition, vol. 2, pp. 11-17, 2014.

[29] A. Sayout, F. Bahi, M. Ouknin et al., "Phytochemical screening and antioxidant activity of four Moroccan Thymus species: T. leptobotrys Murb., T. pallidus Batt., T. broussonetti Boiss. and T. maroccanus Ball," Arabian Journal of Medicinal and Aromatic Plants, vol. 1, pp. 117$128,2015$.

[30] I. Méndez-Tovar, S. Sponza, M. C. Asensio-S-Manzanera, and J. Novak, "Contribution of the main polyphenols of Thymus mastichina subsp. mastichina to its antioxidant properties," Industrial Crops and Products, vol. 66, pp. 291-298, 2015.

[31] A. Djeridane, M. Yousfi, B. Nadjemi, D. Boutassouna, P. Stocker, and N. Vidal, "Antioxidant activity of some Algerian medicinal plants extracts containing phenolic compounds," Food Chemistry, vol. 97, no. 4, pp. 654-660, 2006.

[32] F. Saad, H. N. Mrabti, K. Sayah et al., "Phenolic content, acute toxicity of Ajuga iva extracts and assessment of their antioxidant and carbohydrate digestive enzyme inhibitory effects," South African Journal of Botany, vol. 125, pp. 381-385, 2019.

[33] I. Aouam, Y. El Atki, A. Taroq, F. El Kamari, and A. Abdellaoui, "Chemical composition, antimicrobial, and antioxidant activities of two Moroccan thymus essential oils," Asian Journal of Pharmaceutical and Clinical Research, vol. 12, no. 1, pp. 447-451, 2019.

[34] K. Sayah, I. Marmouzi, H. Naceiri Mrabti, Y. Cherrah, and M. E. A. Faouzi, "Antioxidant activity and inhibitory potential of Cistus salviifolius (L.) and Cistus monspeliensis (L.) aerial parts extracts against key enzymes linked to hyperglycemia," BioMed Research International, vol. 2017, Article ID 2789482, 7 pages, 2017.

[35] D. Granato, F. Shahidi, R. Wrolstad et al., "Antioxidant activity, total phenolics and flavonoids contents: should we ban in vitro screening methods?" Food Chemistry, vol. 264, pp. 471-475, 2018.

[36] A. Phuyal, P. K. Ojha, B. Guragain, and N. K. Chaudhary, "Phytochemical screening, metal concentration determination, antioxidant activity, and antibacterial evaluation of Drymaria diandra plant," Beni-Suef University Journal of Basic and Applied Sciences, vol. 8, no. 1, p. 16, 2019.

[37] G. P. Pidgeon, J. Lysaght, S. Krishnamoorthy et al., "Lipoxygenase metabolism: roles in tumor progression and survival," Cancer and Metastasis Reviews, vol. 26, no. 3-4, p. 503, 2007.

[38] M. N. U. Chy, M. Adnan, A. K. Rauniyar et al., "Evaluation of anti-nociceptive and anti-inflammatory activities of Piper sylvaticum (Roxb.) stem by experimental and computational approaches," Advances in Traditional Medicine, vol. 20, no. 3, p. 327, 2019.

[39] C. Pérez-Guerrero, M. D. Herrera, R. Ortiz, M. Alvarez de Sotomayor, and M. A. Fernández, "A pharmacological study of Cecropia obtusifolia Bertol aqueous extract," Journal of Ethnopharmacology, vol. 76, no. 3, pp. 279-284, 2001.

[40] T. Vezza, A. Rodríguez-Nogales, F. Algieri, M. Utrilla, M. Rodriguez-Cabezas, and J. Galvez, "Flavonoids in inflammatory bowel disease: a review," Nutrients, vol. 8, no. 4, p. 211, 2016. 
[41] N. M. Mostafa, E. A. Abd El-Ghffar, H. G. Hegazy, and O. A. Eldahshan, "New methoxyflavone from Casimiroa sapota and the biological activities of its leaves extract against lead acetate induced hepatotoxicity in rats," Chemistry \& Biodiversity, vol. 15, Article ID e1700528, 2018. 